\title{
Skeletal evidence of torture: How can the past inform the present?
}

\author{
Victoria Tasker
}

\begin{abstract}
This essay addresses skeletal evidence of torture-an area where the current literature is minimal, and as such this essay will provide an overview that can be used as a background review in the future. Three methods of torture are presented-amputation, hobbling and beatings - and their corresponding skeletal indicators. The skeleton is a useful yet somewhat limited resource for biological and forensic anthropologists. However, it is irrefutable that the past can inform the present as shown through a discussion on the role of bioarchaeology in the development of forensic anthropology practices regarding torture.
\end{abstract}

\section{Keywords}

torture, skeletal evidence, bioarchaeology, trauma

\section{Introduction}

Torture is defined by United Nations General Assembly Resolution 39/46 in Article 27(1) of 'The Convention against Torture and Other Cruel, Inhuman or Degrading Treatment or Punishment' as:

any act by which severe pain or suffering, whether physical or mental, is intentionally inflicted on a person for such purposes as obtaining from him or a third person information or a confession ... when such pain or suffering is inflicted by or at the instigation of or with the consent or acquiescence of a public official or other person acting in an official capacity. 
Methods of inflicting torture have existed for thousands of years-physical remains of which have been seen in the archaeological record-and continue to the present day where they present in forensic anthropology contexts. The methods for employing such torture to the human body may have changed as temporal, spatial and political climates have changed. However, the contribution bioarchaeological studies of torture can provide to forensic anthropology analyses and interpretations of torture from skeletal remains in human right abuse contexts should not be underestimated. Subsequently, this essay will investigate how torture can be inferred from specific skeletal indicators in both bioarchaeological and forensic contexts. Using several ancient cases of human skeletal remains, where torture has been identified, three main skeletal indicators of torture and their forensic application within a human rights context will be examined: amputations, hobbling and beatings. This essay will also address the purpose of torture, the differences between identifying torture from the skeleton and soft tissues, and the contribution of bioarchaeology to forensic anthropology.

\section{Overview of torture methods}

Methods of torture can be categorised into two groups: physical torture and psychological torture. As this essay is exploring skeletal evidence of torture, physical torture will be the main focus. There are several forms of physical torture to consider, including but not limited to: amputation; beatings and other localised blows to the body via torturer's hands, fists or feet using hard objects; phalanga-beating of the soles of the feet or palms of the hands; suspension-hanging the victim by a certain body part such as arms or legs; electric torture-electric shocks to the victim; nail torture-the forcible removal of toe and finger nails, forcing objects under the nails or burning of nails; dental torture - extraction or destruction of healthy teeth; pharmacologicaladministration of unnecessary drugs such as anaesthetics or hallucinogenic drugs; asphyxiation procedures_-anything that obstructs normal breathing (for more exhaustive examples and definitions see Henneberg 1999; Cox and Mays 2000; Rodríguez-Martín 2006; Table 1 for a summary). As can be seen in Table 1, these methods can cause both skeletal and soft tissue damage, but can also leave no detectable trace. 
Table 1: Skeletal evidence of torture

\begin{tabular}{|l|l|l|}
\hline Method of torture & Skeletal evidence & $\begin{array}{l}\text { Evidence in } \\
\text { archaeological record }\end{array}$ \\
\hline beatings & yes & unlikely \\
\hline phalanga & yes & unlikely \\
\hline suspension & yes & unlikely \\
\hline electricity & undetermined secondary & unlikely \\
\hline burns & possible & unlikely \\
\hline asphyxiation procedures & rare & yes \\
\hline nail torture & yes & yes \\
\hline dental torture & primary and secondary & primary and secondary \\
\hline pressure & very likely & unlikely \\
\hline strapping & unlikely & yes \\
\hline forced positions & possible & unlikely \\
\hline hand and feet torture & yes & yes \\
\hline sexual torture & more likely in females & yes \\
\hline bullets and other objects & yes & yes \\
\hline pharmacological & possible & yes \\
\hline
\end{tabular}

Source: Adapted, with permission, from Henneberg (1999:74).

The choice of method of torture is often determined by the desired outcome and often by whether the torture method will leave detectable marks on the victim. An example of this can be seen in a case study of 10 child victims of torture at a refugee camp in Kashmiris (Indian subcontinent), as presented by Petersen and Wandall (1995). The purpose of torture was to pacify the civilian population and to acquire information that would not be released otherwise (Petersen and Wandall 1995). In order to obtain such information, the victim would need to be alive. Hence, the torture inflicted was never aimed to kill. The children in this case revealed torture by the way of amputation of phalanges of the hand, bayonet cuts, beatings, burns by heated wire, dripping hot water, acid, cigarettes and a heated iron (Petersen and Wandall 1995). Amongst the stated methods of torture, amputations, hobbling and beatings are most likely to leave skeletal markers. 


\section{Skeletal evidence of torture}

Skeletal markings can reveal that the human skeleton, despite its protective layer of soft tissues, is vulnerable to its external environment. This includes, but is not limited to, trauma and, more specifically, torture. The importance and validity of these determinations of skeletal indicators of torture can only be realised when the limitations of skeletal remains are acknowledged. The ability of the skeleton to record trauma enables forensic anthropologists to use skeletal markings to identify torture and help bring justice to such abhorrent human rights violations (Hunter and Cox 2005). The skeleton, however, does have its limitations. In most circumstances, the soft tissue, being extremely sensitive to its external environment, is more likely to reveal the occurrence of torture. Soft tissue is clearly an unattainable source of information in skeletal remains. Furthermore, the torturer is more likely to choose torture methods and techniques that do not leave a mark on the victim, either on the skeleton or soft tissue. In cases of clandestine graves where decomposition of the body is extensive, parts of the skeleton are often the only remains left (Powell 2010). When this occurs, postmortem damage is more likely to impact the skeleton. Postmortem damage can include depositional loss or damage of bone, faunal scavenging or postmortem mutilation (Powell 2010). All these aspects of postmortem damage limit the accuracy of the forensic anthropologists' interpretations.

Another limitation is the overlap of skeletal markers between different causes. It is common for the same, or very similar, skeletal markers to result from different mechanisms (Ortner 2003). Several of the skeletal markers discussed above may also present in cases of interpersonal violence in warfare or severe accidents. The interpretation of trauma as either violence or torture has clear social connotations. Therefore, such interpretations, particularly those made in a forensic investigation, must be made with extreme caution. These limitations do not and should not impede a forensic investigation; accuracy of interpretation can only improve as methodologies, and the forensic anthropologists that use them, are rigorously tested and exposed to a range of skeletal markings. 


\section{Bioarchaeological evidence for torture}

Amputation has been one of the most prevalent methods of torture evident in skeletal material (Cox and Mays 2000). Amputation of the phalanges of the hands and feet is most common as it inflicts pain and disability on the victim but will not kill them (Knüsel and Smith 2014). With the amputation of phalanges, the torturer is able to inflict such torture up to 20 times (10 hand phalanges and 10 feet phalanges). Amputations can be revealed in the skeleton not only by the absence of phalanx, but primarily by evidence of sharp force trauma (cut marks) to the surrounding bones and, in some circumstances, evidence of bone remodelling. When a fracture (including amputation) occurs on a bone, the bone slowly remodels, generally with help of medical care (Ortner 2003). However, in some cases, if medical care is not received to treat the traumatised bone, as is assumed in the cases of torture victims, the remodelling could occur in an undesired way. These skeletal markings of an amputation would become more pronounced if the amputation had resulted in an infection that caused complications when the bone started healing (Henneberg 1999). Complications that may present on the bone include avascular necrosis, indicated by the death of bone and consequential crumbling and collapsing, and shortening of the bone (Henneberg 1999). The presence of the discussed skeletal markings is generally more reliable as an indication of amputation rather than solely the absence of a phalanx. Small bones, such as phalanges, are easily subjected to taphonomic and diagenetic processes, and the loss of phalange and other small bones is not uncommon in postmortem deposition and/or recovery (Mann et al. 1990). This means that excavation of a grave must be meticulously carried out. As a disabling and painful method of torture, amputation is effective but, thankfully, does leave forensic anthropologists with osteological insights; as does the equally as disabling and painful method of hobbling.

Hobbling is the crushing and beating of the feet (most commonly the soles) so the individual's mobility is restricted to hobbling, and this renders them disabled. This method is often employed to cause a specific social response (Osterholtz 2012). This type of torture is often employed as a display of violence in order to gain social control over the witnessing population (Fellner and Mariner 1997). Osterholtz (2012) examines the social use of hobbling as well as its skeletal manifestations in human skeletal remains recovered from the prehistoric southwest of America. Tarsals, phalanges and metatarsals were identified from 190 fragments, and were analysed and eventually interpreted 
as subjects of hobbling. One foot was distinguished from these 190 fragments following several identification and conjoining processes. The foot appeared to have suffered damage to three main aspects: the medial and lateral aspects of the calcaneus and talus, the plantar surface and the dorsal surface (see Figure 4 in Osterholtz 2012:152). This damage consisted of perimortem crushing (indicated by fractures), which have led to complications in the healing process, scrape marks, cut marks and chop marks. The plantar aspect of the foot shows crushing and peeling (where the periosteum has broken away from the shafts of the metatarsals), which reflects beating of the soles of the feet. The dorsal aspect shows crushing via two blows to the foot. Chop marks (as indicated by arrows in Figure 4 in Osterholtz 2012:152) indicate attempted disarticulation of the foot and eventual complete disarticulation of the foot. It is clear that this method of torture will leave evidence of skeletal trauma in the form of fractures caused by beatings and, in select extreme cases, skeletal evidence of amputation.

Beatings often result in fracturing to the skeleton in the context of torture. Although the most obvious signs of a beating are to the body's soft tissues, Henneberg (1999) suggests that, as a result of trauma from beatings, secondary abnormalities, such as osteitis (inflammation of bone) and periostitis (inflammation of the periosteum), can form after the bone has healed. Fractures on the bone indicate a traumatic event; however, distinguishing that event as being torture is dependent on the nature of healing on the bone and the location of the fractures.

Petersen and Wandall (1995) presented a case study of 10 children who showed signs of torture. Within their findings one child presented with a neglected fracture of the left foot. The neglected nature of the fracture (arch of the foot accentuated and unstable, and the foot was 2 centimetres shorter than the left), in addition to the soft tissue trauma elsewhere on the body and the social context, led to a conclusion of torture.

Meyer et al. (2015) presented the human skeletal remains of a mass grave from the Early Neolithic in Central Europe (Germany) that revealed mass violence and possible torture. Perimortem trauma to the extremities was extensive amongst the 26 individuals (Meyer et al. 2015). Perimortem injuries to the cranial and upper extremities were prevalent, but the perimortem injuries to the lower extremities were overwhelmingly dominant. Perimortem injuries on the upper extremities presented on 19 per cent of the identified fragments compared to $31-42$ per cent of the fibulae and 53-63 per cent of the tibiae 
(see Figure 2 in Meyer et al. 2015:4). This, combined with the obvious focus on the lower extremities, and repeated blows to the lower legs, rendering the victims disabled and immobilised, suggests that the intent was not to kill. Several individuals also presented with healed rib and long-bone fractures, which may suggest that beatings had occurred previously, but they could be an archaeological case of interpersonal violence and not torture. This case revealed that the quantity and nature of the skeletal trauma, as well as its location on the skeleton, can suggest torture as the cause of trauma.

\section{Informing forensic anthropology practice}

The insights that bioarchaeologists can gain from skeletal remains of ancient lifeways are an immense contribution to our knowledge of the past. The historical importance of these insights should not be underestimated. Although the context in which the skeletal analysis is different, the same osteological approach is applicable for forensic anthropology. As is apparent from this essay, there are specific patterns of trauma to the skeleton and specific morphologies of trauma that have been identified to be indicative of evidence of torture in ancient cases. Martin and Harrod (2015) explore how bioarchaeology has contributed to the evolution and practice of forensic anthropology. Biological anthropologists have been able to contribute their arsenal of human skeletal analyses and indicators to the field of forensic anthropology because of the wide and long history of violence by societies. Furthermore, the contribution of archaeology to forensic anthropological methods, such as body excavation and recovery of evidence at burial sites, has shaped forensic anthropology to what is seen today (Dirkmaat et al. 2008). As many torture methods have persisted over many centuries, forensic anthropologists are able to use bioarchaeological studies to understand what skeletal indicators to look for in cases of torture. For example, Kimmerle and Baraybar (2008) discuss how blunt force trauma and the resulting fracturing is often an indication of torture consistent with beatings in modern-day forensic cases. With the large variability in what the modern human mind can conceive, there is no way of ruling out the use of similar methods of torture in today's society. Hence, the forensic anthropologist must be aware of key skeletal indicators of torture (Haglund and Sorg 2002).

Although bioarchaeology contributes to forensic anthropology considerably, it does not always complement it because there are torture methods that do not exhibit skeletal damage. Anaesthetics, hallucinogens, tranquillizers and 
addictive drugs are four examples of pharmacological abuse and torture (Henneberg 1999). If hair is present on a body, it can sometimes reveal traces of pharmaceuticals; however, the forensic anthropologist would be interested in the pharmaceuticals that leave traces in bone. McGrath and Jenkins (2009) test the possibility of bone and bone marrow revealing drugs that were taken (either by choice or force) by the individual when they were alive. They conclude that as drug concentrations in bone were generally higher than those found in corresponding blood specimens, the study reveals a viable way of revealing drugs in the postmortem stage (McGrath and Jenkins 2009). It is clear that the wide range of methods of torture provide a series of challenges for the forensic anthropologist.

As torture is fundamentally a denial of basic human rights, forensic anthropologists must be well learned in the skill of identifying it. The identification of torture found on skeletal remains can have different political ramifications for different political climates (Hunter and Cox 2005). Within these political climates are often differing procedures and protocols the forensic anthropologist must follow. The forensic anthropologist plays a fundamental role in identifying torture in skeletal remains, and hence is influential in its subsequent documentation and place in judicial and legal systems.

The act of torturing another human being has been embedded in the physical core of the human societies for many centuries. The skeletal markings of torture from archaeological contexts, as highlighted in this essay, do inform forensic anthropology practice to some extent. Bioarchaeological cases provide forensic anthropology the tools to understand the history of torture, the expected skeletal evidence, and the societal roll it fills. However, it does not assist in identifying pharmaceuticals and other modern methods of torture.

\section{Acknowledgements}

I would like to thank course tutors Felicity Gilbert and Alyce Cameron for their guidance and support in my forensic anthropology class. I would also like to thank my classmates in forensic anthropology and archaeology for their support and friendship. 


\section{References}

Cox M, Mays S. 2000. Human osteology in archaeology and forensic science. New York (NY): Cambridge University Press.

Dirkmaat D, Cabo L, Ousley S, Symes S. 2008. New perspectives in forensic anthropology. Am J Phys Anthropol. 137(S47):33-52. doi.org/10.1002/ ajpa. 20948

Fellner J, Mariner J. 1997. Cold storage: Super-maximum security confinement in Indiana. New York (NY): Human Rights Watch.

Haglund WD, Sorg MC. 2002. Advancing forensic taphonomy: Purpose, theory, and process. In: WD Haglund, MC Sorg, editors. Advances in forensic taphonomy: Method, theory, and archaeological perspectives. Boca Raton (FL): CRC Press. pp. 3-29.

Henneberg ML. 1999. Forensic evidence of torture: Investigations into human rights violations [Master's thesis]. University of Birmingham.

Hunter J, Cox M. 2005. Forensic archaeology: Advances in theory and practice. London (UK): Routledge.

Kimmerle E, Baraybar J. 2008. Skeletal trauma: Identification of injuries resulting from human rights abuse and armed conflict. 1st ed. Boca Raton (FL): CRC Press. doi.org/10.1201/9781420009118

Knüsel C, Smith M. 2014. The osteology of conflict: What does it all mean? In: C Knüsel, M Smith, editors. The Routledge handbook of the bioarchaeology of human conflict. London(UK): Routledge. pp. 656-694.

Mann RW, Bass WM, Meadows L. 1990. Time since death and decomposition of the human body: Variables and observations in case and experimental field studies. J Forensic Sci. 35(1):103-111. doi.org/10.1520/JFS12806J

Martin D, Harrod R. 2015. Bioarchaeological contributions to the study of violence. Am J Phys Anthropol. 156(S59):116-145. doi.org/10.1002/ ajpa. 22662

McGrath K, Jenkins A. 2009. Detection of drugs of forensic importance in postmortem bone. Am J Forensic Med Pathol. 30(1):40-44. doi.org/ 10.1097/PAF.0b013e31818738c9 
Meyer C, Lohr C, Gronenborn D, Alt K. 2015. The massacre mass grave of Schöneck-Kilianstädten reveals new insights into collective violence in Early Neolithic Central Europe. Proc Natl Acad Sci. 112(36):1121711222. doi.org/10.1073/pnas. 1504365112

Ortner D. 2003. Identification of pathological disorders in human skeletal remains. 2nd ed. London (UK): Academic Press.

Osterholtz A. 2012. The social role of hobbling and torture: Violence in the prehistoric Southwest. Int J Paleopathol. 2(2-3):148-155. doi.org/ 10.1016/j.ijpp.2012.09.011

Petersen H, Wandall J. 1995. Evidence of physical torture in a series of children. Forensic Sci Int. 75(1):45-55. doi.org/10.1016/0379-0738(95)01766-C

Powell K. 2010. Grave concerns: Locating and unearthing human bodies. Bowen Hills (QLD): Australian Academic Press.

Rodríguez-Martín C. 2006. Identification and differential diagnosis of traumatic lesions of the skeleton. In: A Schmitt, E Cunha, J Pinheiro, editors. Forensic anthropology and medicine: Complementary sciences from recovery to cause of death. Totowa (NJ): Humana Press pp. 197221. doi.org/10.1007/978-1-59745-099-7_8

United Nations, General Assembly. The United Nations convention against torture: A handbook on the convention against torture and other cruel, inhuman or degrading treatment or punishment, A/39/46 (26 June 1987). Available from www.ohchr.org/EN/ProfessionalInterest/Pages/CAT.aspx 
This text is taken from the The Human Voyage: Undergraduate Research in Biological Anthropology: Volume 1, 2017, edited by Alison Behie, published 2017 by ANU eView, The Australian National University, Canberra, Australia.

dx.doi.org/10.22459/HV.01.2017.07 